\title{
ANALISIS HAMBATAN SAMPING PADA RUAS JALAN KINIBALU PALANGKA RAYA (STUDI KASUS: STA 0+250 - STA 450)
}

\author{
Ryco Prawira Purba ${ }^{\left(1^{*}\right)}$, Nirwana Puspasari ${ }^{(2)}$ Novrianti $^{\left(3^{* *}\right)}$ \\ Alumni Prodi Teknik Sipil ${ }^{(\mathbf{1})}$ \\ Program Studi Teknik Sipil UM Palangka Raya ${ }^{(2)}$ \\ Program Studi Teknik Lingkungan UM Palangka Raya ${ }^{(3)}$ \\ E-mail: ryco.purba@ gmail.com ${ }^{*}$ \\ novrianti980@gmail.com ${ }^{* *}$
}

\begin{abstract}
ABSTRAK
Jalan Kinibalu Kota Palangka Raya memiliki tipe jalan tak terbagi yaitu: Jalan perkotaan dua-lajur dua-arah. Pengguna jalan sebagian besar adalah pelaku transportasi lokal dalam kota yang dominan menggunakan kendaraan pribadi, dan sebagian dilayani angkutan umum. Sebagian ada juga yang berjalan kaki di sekitar ruas jalan tersebut. Penelitian ini bertujuan menganalisa ruas jalan Kinibalu untuk mengatasi kinerja jalan tersebut.

Data yang digunakan untuk keperluan analisis tersebut digolongkan menjadi dua yaitu data primer diperoleh dari survey geometrik persimpangan, survey arus lalu-lintas, dan survey hambatan samping dan data sekunder berupa peta lokasi dan data jumlah penduduk. Analisis data untuk ruas jalan kota menggunakan Manual Kapasitas Jalan Indonesia (MKJI, 1997).

Berdasarkan hasil dari analisis terhadap ruas jalan Kinibalu Kota Palangka Raya dengan menggunakan MKJI 1997, dapat disimpulkan bahwa hambatan samping yang terjadi pada jalan Kinibalu Kota Palangka Raya termasuk kelas hambatan samping tinggi dengan jenis hambatan samping yang paling dominan yaitu kendaraan parkir atau berhenti dan pada siang hari terdapat PKL (pedagang kaki lima) di sekitar ruas jalan. Akan tetapi ruas jalan Kinibalu tersebut masih layak berfungsi dan terjadinya kemacetan hanya pada saat jam puncak puncak (peak hour) berlangsung saja. Untuk mengatasi hal tersebut, dapat di berikan tanda rambu dilarang parkir di sekitar jalan, serta pemeliharaan zebra cross yang masih ada.
\end{abstract}

\section{Kata kunci: Hambatan Samping, Volume Lalu Lintas, Tingkat Kinerja, Derajat Kejenuhan}


Analisis Hambatan Samping Pada Ruas Jalan Kinibalu ... Ryco $\mathrm{P}^{(1)}$, Nirwana Puspasari ${ }^{(2)}$, Novrianti ${ }^{(3)}$

\section{PENDAHULUAN}

\section{Latar Belakang}

Transportasi merupakan kegiatan perpindahan manusia atau barang dari satu tempat ke tempat lainnya dalam suatu wilayah tertentu.

\section{Terdapat beberapa komponen sistem transportasi, yaitu manusia sebagai pelaku/pengguna kendaraan atau sebagai penumpang, sarana transportasi berupa kendaraan bermotor dan tidak bermotor, angkutan pribadi atau angkutan umum, dan prasarana transportasi yaitu jalan raya yang merupakan kebutuhan yang amat penting bagi manusia.}

Jalan Kinibalu Palangkaraya memiliki tipe jalan tak terbagi yaitu: Jalan perkotaan dua-lajur dua-arah (Sumber: Manual Kapasitas Jalan Indonesia, 1997). Pengguna jalan sebagian besar adalah pelaku transportasi lokal dalam kota yang dominan menggunakan kendaraan pribadi, dan sebagian dilayani angkutan umum. Sebagian ada juga yang berjalan kaki di sekitar ruas jalan tersebut.

Di sekitar ruas jalan terdapat beberapa bangunan umum seperti sekolah, tempat ibadah, serta usaha perekonomian lainnya. Aktifitas arus lalu lintas masih terlihat cukup lancar, kecuali pada waktu jam puncak.

Pada jam puncak ruas jalan tersebut mengalami kemacetan di beberapa titik, saat pengantar sekolah maupun jam pulang sekolah, dan membuat arus lalu lintas menjadi macet (tundaan) yang cukup lama. Adanya kendaraan roda empat yang berhenti dan parkir pada ruas jalan tersebut, di tambahnya lagi dengan adanya penyebrangan jalan, dan pada jam puncak siang hari ada pedagang kaki lima yang berjualan pada ruas jalan tersebut.

\section{Tujuan Penelitian}

1. Untuk mengetahui seberapa besarnya terjadi hambatan samping di ruas jalan Kinibalu Kota Palangka Raya.

2. Untuk mengetahui cara mengatasi hambatan samping pada ruas jalan Kinibalu Kota Palangka Raya.

Manfaat Penelitian
1. Hasil penelitian ini di harapkan dapat berguna bagi instansi pemerintah atau pun sebagai pengetahuan bagi pelaku pengguna lalu lintas.

2. Hasil penelitian diharapkan memberikan Informasi tentang bagaimana pengaruhnya hambatan samping pada ruas jalan tersebut.

3. Dapat menjadi dalam bahan acuan bagi para perencanaan jalan.

\section{TINJAUAN PUSTAKA}

\section{Pengertian Jalan}

Jalan adalah sebagai Prasarana transportasi darat yang meliputi segala bagian jalan, termasuk bangunan pelengkap, dan perlengkapannya yang diperuntukkan bagi lalulintas, yang berada permukaan tanah, diatas permukaan air, kecuali jalan kereta api dan jalan kabel (UU no. 38 tahun 2004 tentang Jalan). Jalan umum adalah jalan yang diperuntukan bagi lalu lintas umum, jalan khusus adalah jalan yang dibangun oleh instansi, badan usaha, perseorangan, atau kelompok masyarakat untuk kepentingan sendiri.

\section{Segmen Jalan Perkotaan atau Semi Perkotaan}

Mempunyai perkembangan secara permanen dan menerus sepanjang atau hampir seluruh jalan, minimum pada satu sisi jalan, apakah berupa perkembangan lahan atau bukan. Jalan di atau dekat pusat perkotaan dengan penduduk lebih dari 100.000 selalu di golongkan dalam kelompok ini. Jalan di daerah perkotaan dengan penduduk kurang dari 100.000 juga di golongkan dalam kelompok ini jika mempunyai perkembangan samping jalan yang permanen dan menerus. (MKJI 1997, hal 251).

\section{Hambatan Samping}

Hambatan samping adalah dampak terhadap kinerja lalu lintas dari aktivitas samping segmen jalan. Dalam MKJI 1997, adapun tipe hambatan samping terbagi menjadi:

1. Pejalan kaki dan Penyebrang jalan

2. Jumlah kendaraan berhenti dan parkir

3. Jumlah kendaraan bermotor yang masuk dan keluar dari lahan samping jalan dan jalan samping 
Analisis Hambatan Samping Pada Ruas Jalan Kinibalu ... Ryco $\mathrm{P}^{(1)}$, Nirwana Puspasari ${ }^{(2)}$, Novrianti ${ }^{(3)}$

4. Arus kendaraan lambat, yaitu arus total (kend/jam) sepeda, becak, delman, pedati, traktor, dan sebagainya.

seperti pejalan kaki (bobot $=0,5$ ) kendaraan umum atau kendaraan lain berhenti (bobot $=$ $1,0)$, kendaraan masuk atau keluar sisi jalan (bobot $=0,7)$ dan kendaraan lambat $($ bobot $=$ 0,4) (MKJI 1997- hal 5-10).

Jumlah terbobot $=\sum(\mathrm{F} \times$ Tipe Hambatan Samping)

dimana:

$\mathrm{F}=$ Faktor hambatan samping

Tipe Hambatan Samping

$=$ Pejalan Kaki, Kendaraan Berhenti, Kendaraan Masuk atau Keluar Sisi Jalan, dan Kendaraan Lambat.

\section{Kecepatan Arus Bebas (FV)}

Kecepatan arus bebas (FV) didefinisikan sebagai kecepatan pada tingkat arus nol, yaitu kecepatan yang akan dipilih pengemudi jika mengendarai kendaraan bermotor tanpa dipengaruhi oleh kendaraan bermotor lain di jalan. Kecepatan arus bebas telah diamati melalui pengumpulan data lapangan, dimana hubungan antara kecepatan arus bebas dengan kondisi geometrik dan lingkungan telah ditentukan dengan metode regresi. Kecepatan arus bebas kendaraan ringan telah dipilih sebagi kriteria dasar untuk kinerja segmen jalan pada arus $=0$. Kecepatan arus bebas untuk kendaraan berat dan sepeda motor juga diberikan sebagai referensi. Kecepatan arus bebas untuk mobil penumpang biasanya 10-15\% lebih tinggi dari tipe kendaraan ringan lain.

\section{Persamaan penentuan kecepatan arus bebas}

$\mathrm{FV}=(\mathrm{FVo}+\mathrm{FVw}) \times \mathrm{FFV} s \mathrm{~F} \times \mathrm{FFV} c \mathrm{~s}$

dimana:

$$
\begin{aligned}
\mathrm{FV}= & \begin{array}{l}
\text { Kecepatan arus bebas kendaraan ringan } \\
\text { pada kondisi lapangan }(\mathrm{km} / \mathrm{jam})
\end{array} \\
\mathrm{FVo}= & \begin{array}{l}
\text { Kecepatan arus bebas dasar kendaraan } \\
\text { ringan pada jalan yang diamati }
\end{array} \\
\mathrm{FVw}= & \begin{array}{l}
\text { Penyesuaian kecepatan untuk lebar } \\
\text { jalan }(\mathrm{km} / \mathrm{jam})
\end{array} \\
\mathrm{FFVsf}= & \begin{array}{l}
\text { Faktor penyesuaian untuk hambatan } \\
\text { samping dan lebar bahu atau jarak }
\end{array}
\end{aligned}
$$

kereb penghalang

FFVcs = Faktor penyesuaian kecepatan untuk ukuran kota

\section{Volume Lalu Lintas (Q)}

Volume lalu lintas adalah jumlah kendaraan yang melewati suatu titik per satuan waktu pada lokasi tertentu. Untuk mengukur jumlah lalu lintas, biasanya dinyatakan dalam kendaraan per hari, smp per jam, dan kendaraan per menit (MKJI 1997).

$\mathrm{Q}=\sum(\mathrm{q} \times \mathrm{emp})$

dimana:

$\mathrm{Q}=$ Volume lalu lintas $(\mathrm{smp} / \mathrm{jam})$

$\mathrm{q} \quad=$ Volume lalu lintas (kend/jam)

Emp $=$ Ekivalensi mobil penumpang

\section{Kapasitas (C)}

Kapasitas didefinisikan sebagai arus maksimum melalu titik di jalan yang dapat dipertahankan per satuan jam pada kondisi tertentu. Untuk jalan dua-lajur dua-arah, kapasitas ditentukan untuk arus dua arah(kombinasi dua arah), tetapi untuk jalan dengan banyak lajur, arus dipisahkan per arah dan kapasitas ditentukan per lajur

Manual Kapsitas Jalan Indonesia (MKJI 1997), Memberikan metoda untuk memperkirakan kapsitas jalan di Indonesia dengan rumus:

$\mathrm{C}=\mathrm{C}_{\mathrm{o}} \times \mathrm{FC}_{\mathrm{w}} \times \mathrm{FC}_{\mathrm{sp}} \times \mathrm{FC}_{\mathrm{sf}} \times \mathrm{FC}_{\mathrm{CS}}$

dimana:

$\mathrm{C} \quad=$ Kapasitas (smp/jam)

Co = Kapasitas dasar (smp/jam)

$\mathrm{FCw}=$ Faktor Penyesuaian akibat lebar jalur lalu lintas

FCsp $=$ Faktor Penyesuaian akibat pemisah arah

FCsf $=$ Faktor Penyesuaian akibat hambatan samping

FCcs $=$ Faktor Penyesuaian untuk ukuran kota

\section{Derajat Jenuh (Degree Of Saturation, DS)}

Derajat kejenuhan adalah perbandingan dari nilai volume (nilai arus) lalu lintas terhadap kapasitasnya. Ini merupakan gambaran apakah suatu arus jalan mempunyai masalah atau tidak. Berdasarkan asumsi jika ruas jalan makin dekat dengan kapasitasnya kemudian bergerak makin 
terbatas. Berdasarkan definisi derajat kejenuhan, DS di hitung sebagai berikut :

$\mathrm{DS}=\frac{\mathrm{Q}}{\mathrm{C}}$

dimana:

$\mathrm{Q}=$ Arus Lalu lintas (smp/jam)

$\mathrm{C}=$ Kapasitas (smp/jam)

Derajat jenuh di hitung dengan menggunakan arus dan kapasitas dinyatakan dalam smp/jam. DS digunakan untuk analisa perilaku lalu lintas berupa kecepatan.

\section{METODE PENELITIAN}

Bagan alir penelitian sebagai berikut:

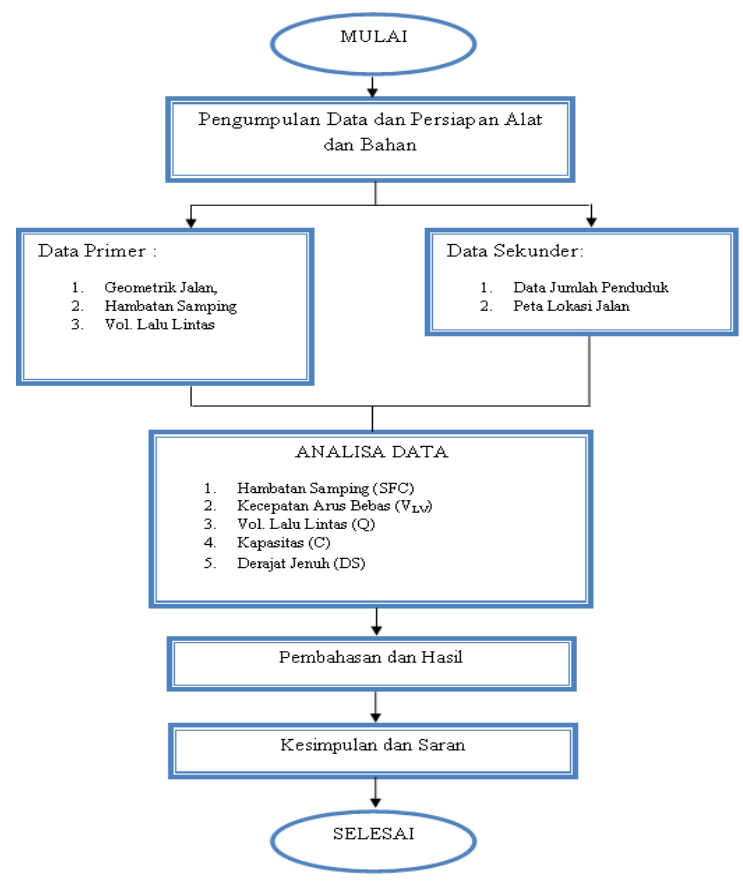

\section{ANALISIS DAN HASIL}

\section{Data dan Hasil Survey Lapangan}

Pengumpulan data survei lapangan yang mencakup data lalu lintas, data geometrik, hambatan samping dan lingkungan yang dilakukan selama tiga hari dimulai pada hari Senin 27 Febuari 2017, hari Rabu 8 Maret 2017 dan hari Kamis 2 Maret 2017. Data yang diambil pada pagi hari mulai pukul $05.30 \mathrm{WIB}$ sampai dengan pukul 07.30 WIB dan siang hari mulai pukul 11.00 WIB sampai dengan pukul 13.00 WIB.
Untuk mengetahui pengaruh jumlah hambatan samping (side friction) terhadap kapasitas jalan dan derajat kejenuhan disepanjang segmen jalan yang diamati, dibutuhkan sejumlah data yang meliputi data jumlah kejadian hambatan samping berdasarkan tipe hambatan samping. Dan untuk perhitungan analisa berdasarkan MKJI 1997.

\section{Data Geometrik Jalan}

Kondisi geometrik jalan perkotaan didapat dari hasil pengukuran dilapangan dengan menggunakan alat pendukung terutama meteran dan pengamatan langsung tentang kondisi lingkungan sekitar lokasi. Data tersebut dapat dilihat pada Gambar 4.1 dan Tabel 4.1 dibawah.

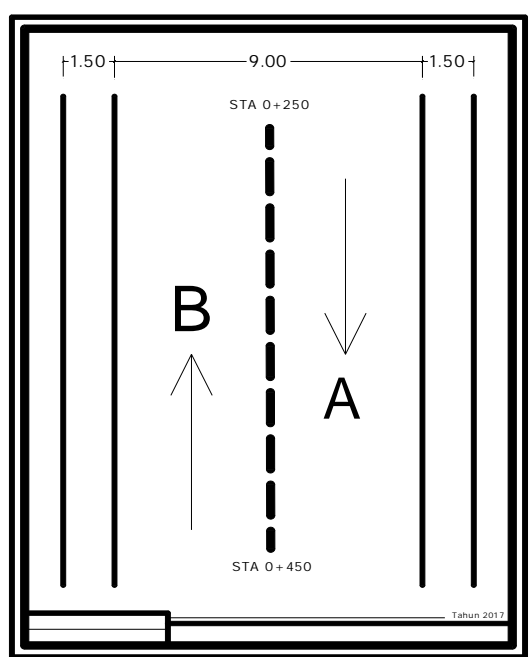

Gambar 4.1 Dengan tipe jalan 2/2 UD, tanpa media

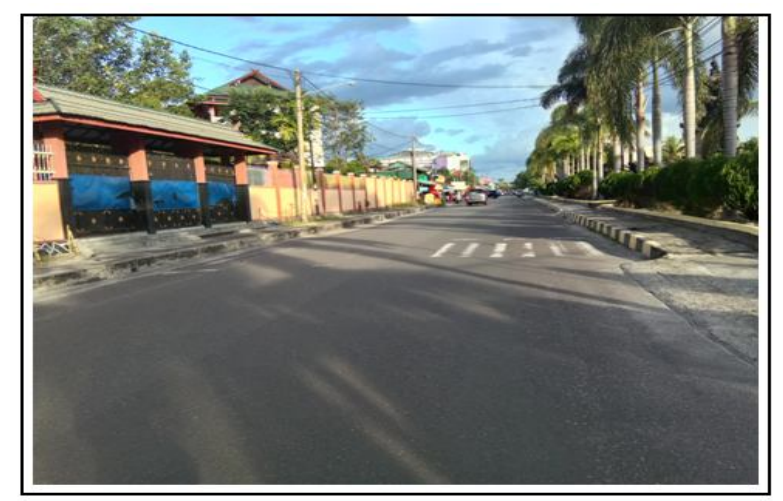

Gambar 4.2 Jalan Kinibalu Palangka Raya, dengan tipe jalan 2/2 UD.

\begin{tabular}{|c|c|c|c|c|c|}
\hline \multirow[b]{2}{*}{ No } & \multirow[b]{2}{*}{ Stasiun } & \multirow[b]{2}{*}{$\begin{array}{l}\text { Lebar jalur lalu } \\
\text { Lintas }\end{array}$} & \multicolumn{2}{|c|}{ Lebar bahu Jalan } & \multirow{2}{*}{$\begin{array}{c}\text { Tipe } \\
\text { lingkungan } \\
\text { jalan }\end{array}$} \\
\hline & & & $\begin{array}{c}\text { Sisi A } \\
(\mathrm{m})\end{array}$ & $\begin{array}{l}\text { Sisi B } \\
(\mathrm{m})\end{array}$ & \\
\hline 1 & $0+250$ & 9,3 & 1,5 & 1,5 & Komersial \\
\hline 2 & $0+450$ & 9,3 & 1,5 & 1,5 & Komersial \\
\hline \multicolumn{2}{|r|}{ Total } & 18,6 & 3 & 3 & \\
\hline \multicolumn{2}{|c|}{ Rata-Rata } & 9,3 & \multicolumn{2}{|c|}{1,5} & \\
\hline
\end{tabular}


Analisis Hambatan Samping Pada Ruas Jalan Kinibalu ... Ryco $\mathrm{P}^{(1)}$, Nirwana Puspasari ${ }^{(2)}$, Novrianti ${ }^{(3)}$

\section{Volume Lalu Lintas}

Data lalu-lintas adalah data yang diperoleh dengan cara mencatat semua jenis kendaraan bermotor dan tidak bermotor yang melewati masing-masing Lajur dengan interval waktu 15 menit. Dari hasil perhitungan survey tersebut data yang dipakai adalah hasil rata-rata arus lalu-lintas selama 3 hari dengan periode 1 jam, didapat volume arus lalu-lintas total dan jam puncak (peak hour) bisa dilihat pada tabel dan gambar dibawah ini.

Berikut adalah data dari perhitungan volume lalu lintas yang ada di Jalan Kinibalu Palangkaraya (STA 0+250 sampai dengan STA 0+450).

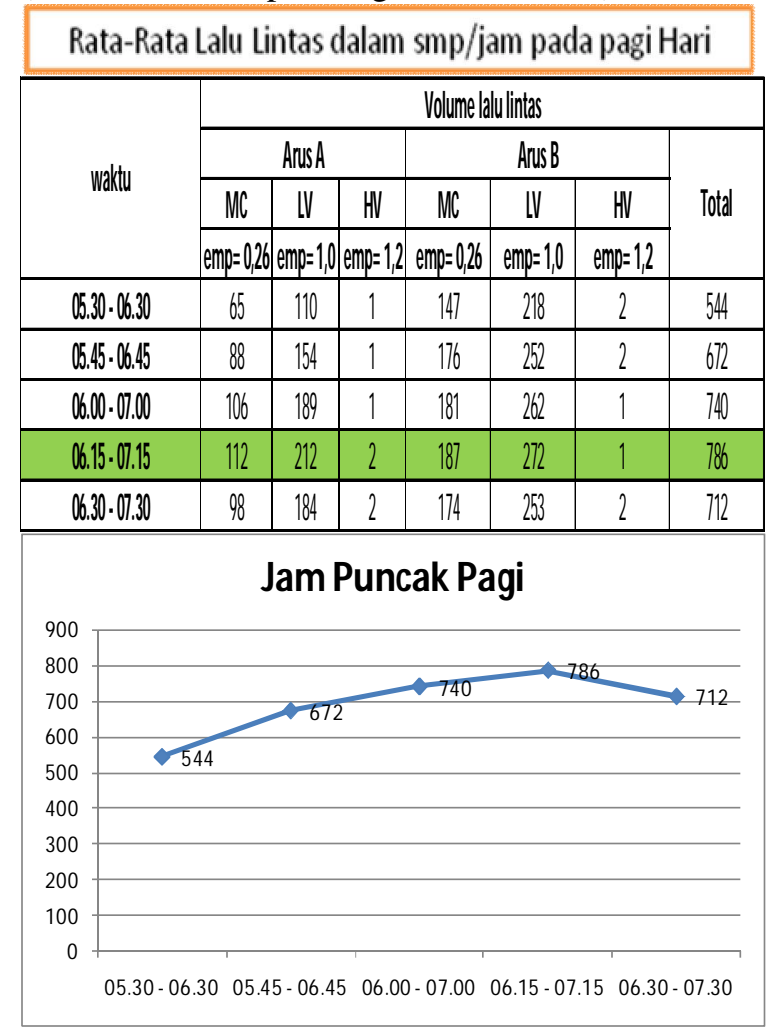

Gambar Jam Puncale (Peok hour) pada pagi hat adatah $786 \mathrm{mp} / \mathrm{jam}$, olume Lalu-lintas Puncak Ualan Linibalu palanglarays

\begin{tabular}{|c|c|c|c|c|c|c|c|}
\hline \multicolumn{8}{|c|}{ Rata-Rata Lalu Lintas dalam smp/jam pada Siang Hari } \\
\hline \multirow{4}{*}{ wakku } & \multicolumn{6}{|c|}{ Volume lalulintas } & \multirow{4}{*}{ Total } \\
\hline & \multicolumn{3}{|c|}{ AnsA } & \multicolumn{3}{|c|}{ AnusB } & \\
\hline & MC & LV & HV & MC & LV & HN & \\
\hline & \multicolumn{3}{|c|}{ 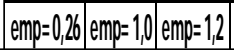 } & emp $=0,26$ & emp=1,0 & emp=1.2 & \\
\hline $11,00 \cdot 12,00$ & 136 & 209 & 3 & 118 & 206 & 1 & 680 \\
\hline $11,15 \cdot 12.15$ & 136 & 204 & 5 & 129 & 221 & 6 & 702 \\
\hline $1130 \cdot 12,30$ & 139 & 219 & 6 & 136 & 259 & 5 & 764 \\
\hline $11,45 \cdot 12,45$ & 145 & 229 & 5 & 134 & 291 & 3 & 806 \\
\hline $12,00 \cdot 13,00$ & 141 & 235 & 4 & 125 & 293 & 2 & 800 \\
\hline
\end{tabular}

\section{Jam Puncak Siang}

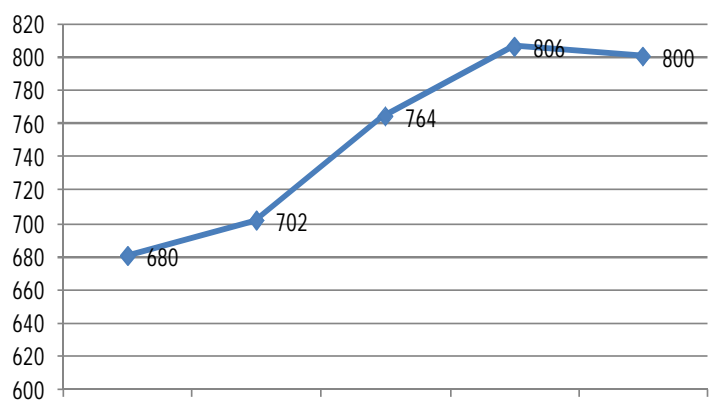

11.00-12.00 $11.15-12.15 \quad 11.30-12.30 \quad 11.45-12.45 \quad 12.00-13.00$

\section{Analisis Volume Lalu Lintas}

\section{Gambar Jam Puncal (peok how) pada siang har adalah 206 smp/an, volume Lalu-lintas Puncal Jalan kinibalu palangkarayal}

Data di ambil dari jam puncak (peak hour) yang terjadi dimana, kejadian terjadi pada pagi dan siang hari.

a. Volume pagi hari terdapat jam puncak ratarata pada jam $06.15 \mathrm{~s} / \mathrm{d} 07.15 \mathrm{Wib}$.

$(\mathrm{Q}$ Pagi $)=786 \mathrm{smp} / \mathrm{jam}$

b. Volume siang hari terdapat jam puncak ratarata pada jam $11.45 \mathrm{~s} / \mathrm{d} 12.45 \mathrm{Wib}$.

$$
(\mathrm{Q} \text { Siang })=806 \mathrm{smp} / \mathrm{jam}
$$

\section{Analisis Hambatan Samping}

Pengambilan data hambatan samping ini dilakukan bersamaan dengan pengambilan data volume lalu lintas dengan derah pengamatan dalam radius 200 meter berdasarkan ketentuan Manual Kapasitas Jalan Indonesia (MKJI 1997) . Pengamatan frekuensi hambatan samping pada kedua segmen jalan yang diamati berdasarkan pada:

1. Jumlah pejalan kaki berjalan atau menyebrang sepanjang segmen jalan

2. Jumlah kendaraan berhenti dan parkir

3. Jumlah kendaraan keluar dan masuk ke atau dari lahan samping jalan atau sisi jalan

4. Kendaraan yang bergerak lambat

Berikut adalah Tabel dan Grafik dalam Jam Puncak Hambatan Samping dan Hambatan Samping pada jam puncak lalu lintas. 
Analisis Hambatan Samping Pada Ruas Jalan Kinibalu ... Ryco $\mathrm{P}^{(1)}$, Nirwana Puspasari ${ }^{(2)}$, Novrianti ${ }^{(3)}$

Berdasarkan data di ambil dari jam puncak (peak hour), yang terjadi dimana, kejadian pada pagi dan siang, dapat di peroleh hasil perhitungan hambatan samping, menggunakan rumus (2.1).

Untuk menghitung hambatan samping (side friction), frekuensi kejadian hambatan samping terlebih dahulu harus di kalikan dengan faktor bobot (wighting factor) dari tipe kejadian hambatan samping, dengan perhitungan di pagi total dan siang totat, dengan tipe jalan $2 / 2$ UD dalam STA $0+250$ sampai dengan STA $0+450$.

a. Data Perhitungan Hambatan Samping jam puncak (peak hour) pada Pagi hari

1. Pejalan Kaki $=244 \quad \times 0,5=121,8$

2. Kendaraan parkir $/$ berhenti $=249,7 \times 1,0=$ 249,7

3. Kendaraan keluar/masuk sisi jalan = $86 \times 0,7=60,4$

4. Kendaraan bergerak lambat $287 \times 0,4=114,8$

Jumlah Hambatan Samping $=121,8+249,7+60,4+114,8=546,7$

Sehingga termasuk dalam kelas hambatan samping Tinggi (H), (500-899), lihat Tabel 2.1.

Dari hasil analisis tersebut dapat di simpulkan bahwa hambatan samping paling dominan adalah kendaraan parkir atau berhenti pada ruas jalan tersebut dengan nilai 249,7 (45,6 $\%)$.

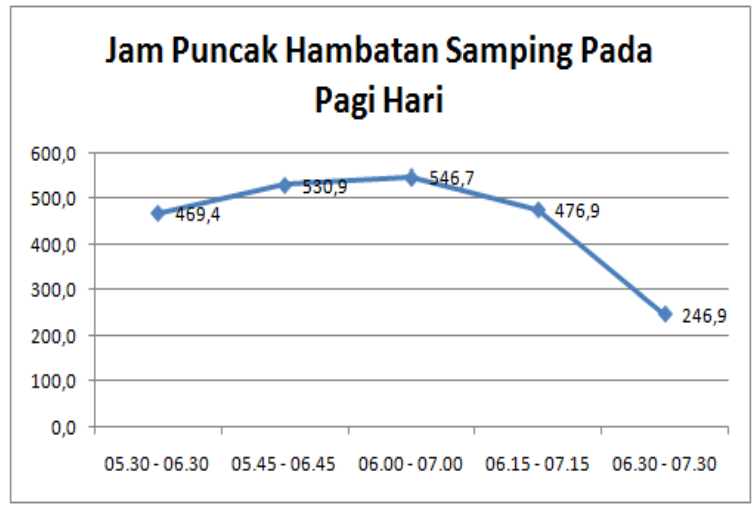

b. Data Perhitungan Hambatan Samping jam puncak (peak hour) pada siang hari

1. Pejalan Kaki $=289 \times 0,5=144,5$
2. Kendaraan Parkir/berhenti= $312,7 \times 1,0=312,7$

3. Kendaraan keluar/masuk sisi jalan = $101 \times 0,7=70,7$

4. Kendaraan bergerak lambat = $164 \times 0,4=65,6$

Jumlah Hambatan Samping

$=144,5+312,7+70,7+65,6=593,5$

Sehingga termasuk dalam kelas hambatan samping Tinggi (H), (500-899), lihat Tabel 2.1.

Dari hasil analisis tersebut dapat di simpulkan bahwa hambatan samping paling dominan adalah kendaraan parkir atau berhenti pada ruas jalan tersebut dengan nilai 312,7 (52,6 $\%)$.

Jam Puncak Hambatan Samping Pada Siang Hari

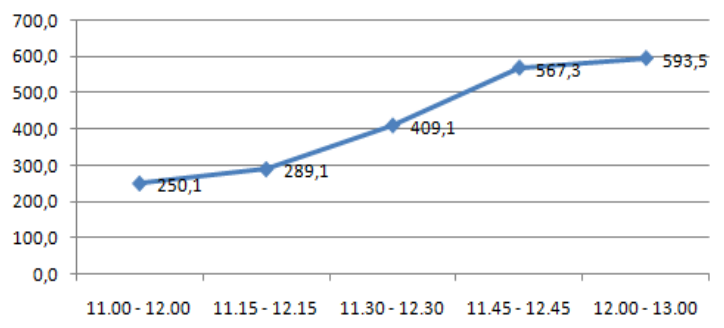

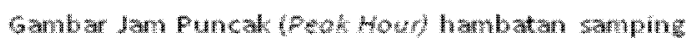

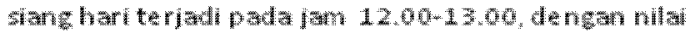

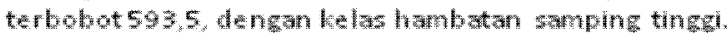

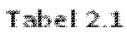

Data Perhitungan Hambatan Samping pada jam puncak (peak hour) lalu lintas pada Pagi hari

1. Pejalan Kaki $=210 \quad \times 0,5=105$

2. Kendaraan Parkir/berhenti $\quad=200,7 \times$ $1,0=200,7$

3. Kendaraan keluar/masuk sisi jalan $=90$ $\times 0,7=63$

4. Kendaraan bergerak lambat $=271 \times$ $0,4=108,3$

Jumlah Hambatan Samping $=105+200,7+63+$ $108,3=476,9$ 
Analisis Hambatan Samping Pada Ruas Jalan Kinibalu ... Ryco $\mathrm{P}^{(1)}$, Nirwana Puspasari( ${ }^{(2)}$, Novrianti ${ }^{(3)}$

Sehingga termasuk dalam kelas hambatan samping Sedang (M), (300-499), lihat Tabel

Gambar Puncak (Peok houn) hambatan samping pag hari terjadi padajan $06.00-07.00$. dengan nilai terbobot 546,7 , dengan kelas hambatan samping tinggi. Tabel 2.1

2.1 .

Dari hasil analisis tersebut dapat di simpulkan bahwa hambatan samping lebih dominan adalah kendaraan parkir atau berhenti pada ruas jalan tersebut dengan nilai 200,7 (42.1 $\%)$.
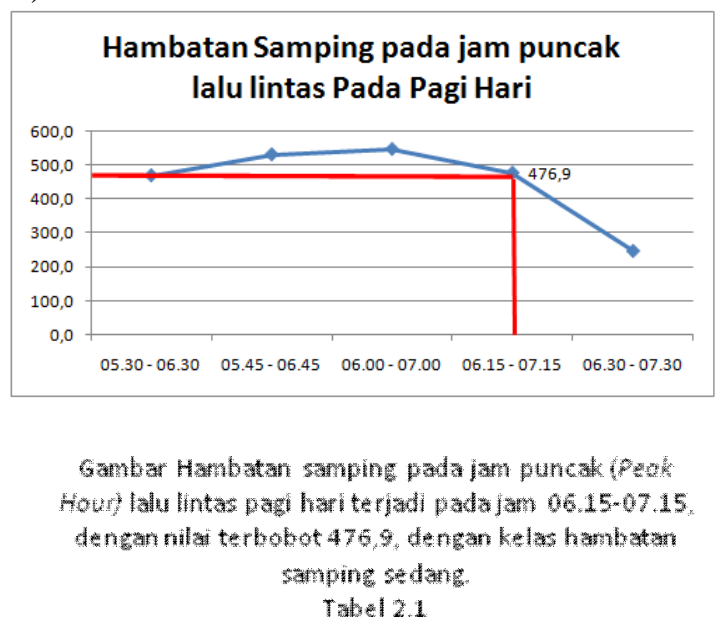

a. Data Perhitungan Hambatan Samping pada jam puncak (peak hour) lalu lintas pada Pagi hari

1. Pejalan Kaki

$256 \times 0,5=128$

2. Kendaraan Parkir/berhenti

$307,0 \times 1,0=307,0$

3. Kendaraan keluar/masuk sisi jalan = $64,4 \times 0,7=64,4$

4. Kendaraan bergerak lambat $169,67 \times 0,4=67,9$

Jumlah Hambatan Samping $=128+$ $307,0+64,4+67,9=567,3$

Sehingga termasuk dalam kelas hambatan samping Tinggi (H), (500-899), lihat Tabel 2.1 .

Dari hasil analisis tersebut dapat di simpulkan bahwa hambatan samping lebih dominan adalah kendaraan parkir atau berhenti pada ruas jalan tersebut dengan nilai $307(54,1 \%)$.
Hambatan Samping pada jam puncak lalu lintas Pada Siang Hari

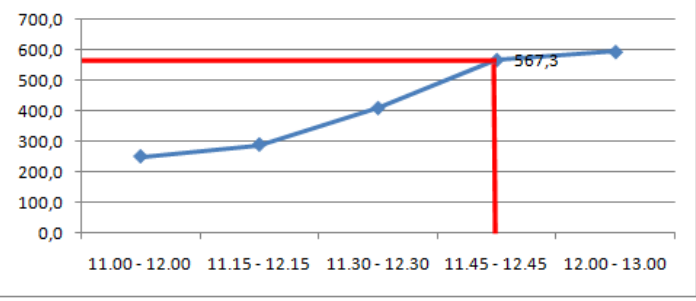

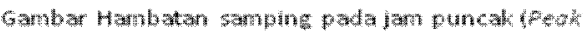

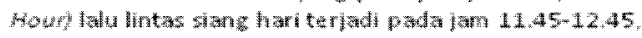

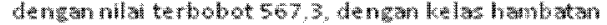

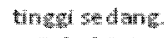

\section{Kecepatan Arus Bebas (FV)}

Perhitungan Kecepatan Arus Bebas yang terjadi pada pagi dan siang hari

Diketahui:

Fvo $=$ Kecepatan arus bebas dasar kendaraan ringan Semua Kendaraan $($ rata-rata $)=42$, Tabel 2.2 .

$\mathrm{FVw}=$ Penyesuaian kecepatan untuk lebar jalan ( $\mathrm{km} / \mathrm{jam})$ lebar jalur lalu lintas efektif 9 m dengan tipe jalan 2/2 UD tanpa median $=4$ $\mathrm{km} / \mathrm{jam}$, Tabel 2.3.

FFVsf = Lebar bahu efektif $1,5 \mathrm{~m}$, dengan kelas hambatan samping sedang = 0,96 m untuk pagi hari, dan untuk kelas hambatan samping tinggi $=0,90 \mathrm{~m}$. Dengan tipe jalan 2/2 UD tanpa median. Tabel 2.4

FFVcs $=$ Jumlah penduduk kota palangka raya memilik populasi penduduk dalam angka 259.865 (sumber: BPS Kota Palangka Raya, dalam angka 2015), dengan data tersebut 100.000 jiwa sampai dengan 500.000 jiwa $(0,1-0,5)=0,93$.

Tabel 2.5. 
Analisis Hambatan Samping Pada Ruas Jalan Kinibalu ... Ryco $\mathrm{P}^{(1)}$, Nirwana Puspasari ${ }^{(2)}$, Novrianti ${ }^{(3)}$

\section{Hasil Perhitungan Kecepatan Arus Bebas Pada Pagi dan Siang Hari}

a. Kecepatan Arus Bebas rata-rata Kendaraan campuran pada jam Puncak Pagi hari

$$
\begin{aligned}
\mathrm{FV} & =(\text { Fvo }+ \text { FVw }) \times \text { FFVsf } \times \text { FFVcs } \\
& =(42+4) \times 0,96 \times 0,93 \\
& =41,07 \mathrm{Km} / \mathrm{jam}
\end{aligned}
$$

b. Kecepatan Arus Bebas rata-rata Kendaraan campuran pada jam Puncak Siang hari

$$
\begin{aligned}
\mathrm{FV} & =(\mathrm{Fvo}+\mathrm{FVw}) \times \mathrm{FFV} \text { sf } \times \text { FFV cs } \\
& =(42+4) \times 0,90 \times 0,93 \\
& =38,50 \mathrm{Km} / \mathrm{jam}
\end{aligned}
$$

c. Kecepatan Arus Bebas Kendaraan ringan pada jam puncak Pagi hari

$$
\begin{aligned}
\mathrm{FV} & =(\mathrm{Fvo}+\mathrm{FVw}) \times \text { FFVsf } \times \text { FFVcs } \\
& =(44+4) \times 0,90 \times 0,93 \\
& =42,85 \mathrm{Km} / \mathrm{jam}
\end{aligned}
$$

d. Kecepatan Arus Bebas Kendaraan ringan pada jam puncak Siang hari

$$
\begin{aligned}
\mathrm{FV} & =(\mathrm{Fvo}+\mathrm{FVw}) \times \mathrm{FFVsf} \times \mathrm{FFVcs} \\
& =(44+4) \times 0,90 \times 0,93 \\
& =40,18 \mathrm{Km} / \mathrm{jam}
\end{aligned}
$$

\section{Kapasitas (C)}

Perhitungan Kapasitas yang terjadi pada pagi dan siang hari

Diketahui:

Co $\quad=$ Kapasitas dasar $(\mathrm{smp} / \mathrm{jam})$,

Tipe Jalan 2/2 UD tanpa median, sehingga kapasitas dasar untuk pagi dan siang hari yaitu $=2900 \mathrm{smp} / \mathrm{jam}$ Tabel 2.9.

$\mathrm{FCw}=$ Faktor Penyesuaian akibat lebar jalur lalu lintas,

Lebar efektif jalan yaitu $9 \mathrm{~m}$, tipe jalan $2 / 2$ UD tanpa median $=1,25 \mathrm{~m}$ Tabel 2.10.

FCsp $=$ Faktor Penyesuaian akibat pemisah arah,

Faktor pembagian arah, karena terdapat 2 arah, maka nilai tersebut diperoleh dengan perbandingan besarnya volume pada masing-masing lajur, untuk Pagi hari berbanding 40:60 dan untuk siang hari 50:50 Tabel 2.11

FCsf = Faktor Penyesuaian akibat hambatan samping,

Untuk lebar bahu $1,5 \mathrm{~m}$ pada pagi hari dengan kelas hambatan samping sedang $(M)=0,95$, sedangkan untuk lebar bahu $1,5 \mathrm{~m}$ pada siang hari dengan kelas hambatan samping tinggi $(\mathrm{H})=0,90$, dengan tipe jalan 2/2 UD tanpa median Tabel 2.12

FCcs $=$ Faktor Penyesuaian untuk ukuran kota,

Jumlah penduduk kota palangka raya memilik populasi penduduk dalam angka 259.865 (sumber: BPS Kota Palangka Raya, dalam angka 2015), dengan data tersebut 100.000 jiwa sampai dengan 500.000 jiwa $(0,1-0,5)$ $=0,90$ Tabel 2.14.

\section{Hasil Perhitungan Nilai Kapasitas Pada Pagi dan Siang Hari}

a. Kapasitas pada Pagi hari

$$
\begin{aligned}
\mathrm{C}= & \mathrm{Co} \times \mathrm{FCw} \times \mathrm{FCsp} \times \mathrm{FCsf} \times \\
& \text { FCcs }(\mathrm{smp} / \mathrm{jam}) \\
= & 2900 \times 1,25 \times 0,94 \times 0,95 \times 0,9 \\
= & 2913,41 \mathrm{smp} / \mathrm{jam}
\end{aligned}
$$

b. Kapasitas Pada Siang hari

$$
\begin{aligned}
\mathrm{C}= & \mathrm{Co} \times \mathrm{FCw} \times \mathrm{FCsp} \times \mathrm{FCsf} \times \\
& \mathrm{FCcs}(\mathrm{smp} / \mathrm{jam}) \\
= & 2900 \times 1,25 \times 1 \times 0,9 \times 0,9 \\
= & 2936,25 \mathrm{smp} / \mathrm{jam}
\end{aligned}
$$

\section{Derajat Jenuh (DS)}

\section{Perhitungan Derajat Kejenuhan (Degree of Saturated)}

$$
\mathrm{DS}=\mathrm{Q} / \mathrm{C}
$$

Dimana:

$\mathrm{Q}=$ Arus Lalu lintas (smp/jam)

$\mathrm{C}=$ Kapasitas (smp/jam) 
Analisis Hambatan Samping Pada Ruas Jalan Kinibalu ... Ryco $\mathrm{P}^{(1)}$, Nirwana Puspasari ${ }^{(2)}$, Novrianti ${ }^{(3)}$

a. Derajat jenuh (DS) Pada Pagi hari

$$
\begin{aligned}
\mathrm{DS} & =\frac{Q}{C} \\
& =\frac{786 \mathrm{smp} / \mathrm{jam}}{2914 \mathrm{smp} / \mathrm{jam}} \\
& =0,269
\end{aligned}
$$

b. Derajat jenuh (DS) Pada Siang hari

$$
\begin{aligned}
\mathrm{DS} & =\frac{Q}{C} \\
& =\frac{806 \mathrm{smp} / \mathrm{tam}}{2937 \mathrm{smp} / \mathrm{jam}} \\
& =0,274
\end{aligned}
$$

\section{Kecepatan Ruang Rata-Rata $\left(\mathrm{V}_{\mathrm{LV}}\right)$}

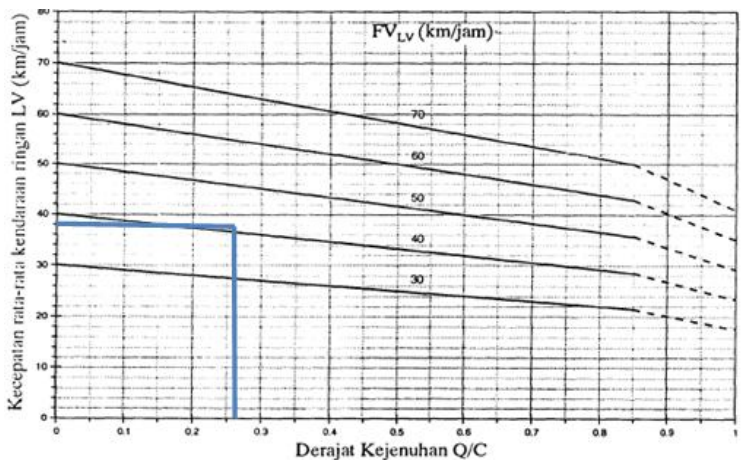

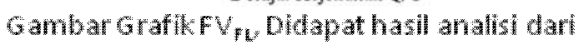
kecepat an arus bebas rata-lat a kendaraan campuran padapag harl yätu $F V=41$ dan nilai derajat jenuhyaitu 0.269 di dapatlahnilat sebesar $=38 \mathrm{~km} / \mathrm{jam}$

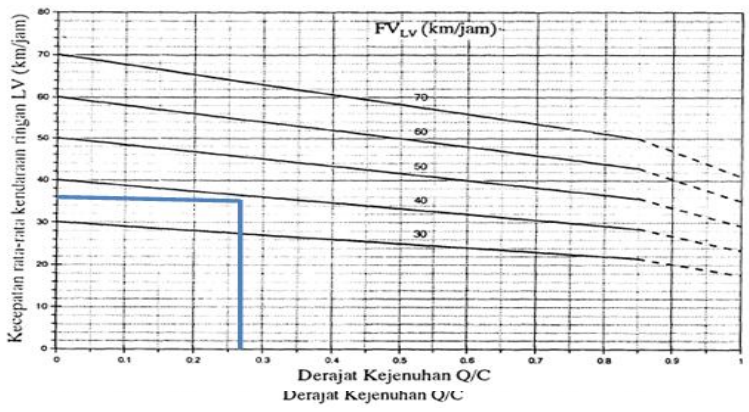

Gambar Graflef $V_{\text {t }}$ Didapat hasil analis darl kecepatan arus bebaskendaraan ringan patapagi harlyaltuFV $=42.8$ dan nual derajat jenuhyaitu 0.269 di dapatiah $=39 \mathrm{~km} / \mathrm{jam}$.

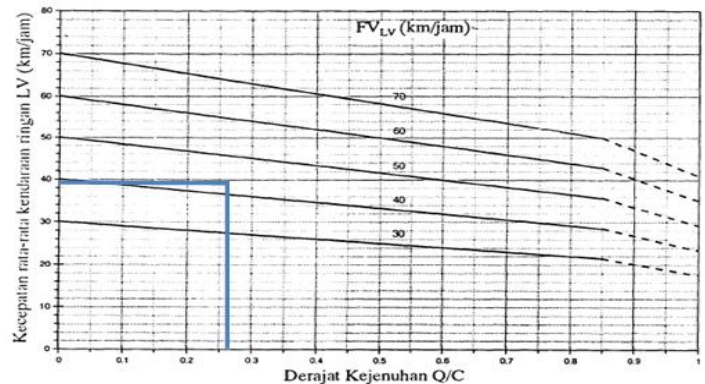

Gambar Grafik FV $V_{1}$ Didapat hasil analisi dan kecepatanarus bebas kendaran ringanpada pagi han yaltuFV $=42,8$ dan nilaí derajatjenuh yaitu 0.269 di dapatlah $=39 \mathrm{~km} / \mathrm{jam}$.

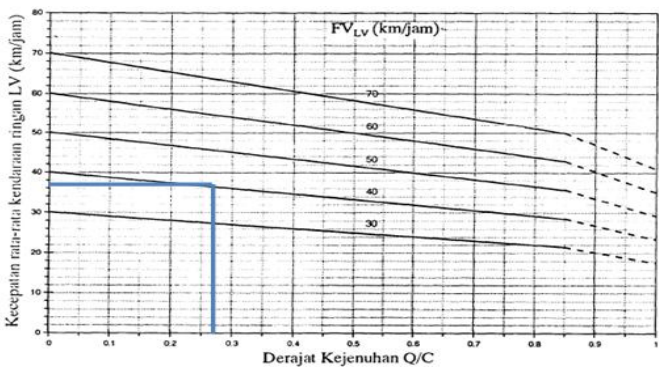

Gambar orafik Fv ${ }_{1}$ Didapat hasil andlsi dan kecepatan rata-ataarus bebaskendaranringan padasiang hariyatu $\mathrm{F}=40,18$ dan nilal derat Jenthyatu0. 274 didapatlah $=37 \mathrm{~km} / \mathrm{Jm}$.

\section{KESIMPULAN DAN SARAN}

\section{Kesimpulan}

Berdasarkan hasil analisa terhadap hambatan samping pada ruas jalan kinibalu kota Palangka Raya dalam STA 0+250 sampai dengan STA 0+450 (200 m) Berdasarkan MKJI 1997, dapat diambil kesimpulan sebagai berikut:

1. Hasil perhitungan survey arus lalu-lintas selama 3 hari, yaitu hari Senin 27 Febuari 2017, Rabu 8 Maret 2017 dan Kamis 2 Maret 2017 dengan interval waktu selama 2 jam pada pagi hari ( 05.30-07.30) dan 2 jam pada siang hari (11.00-13.00).

Dari hasil analisis didapatkan besar volume lalu lintas rata-ratanya, yaitu sebesar 786 smp/jam terjadi pada jam puncak pagi (06.1507.15) dan sebesar 806 smp/jam pada jam puncak siang (11.45-12.45) untuk total dua arah. 
Analisis Hambatan Samping Pada Ruas Jalan Kinibalu ... Ryco $\mathrm{P}^{(1)}$, Nirwana Puspasari ${ }^{(2)}$, Novrianti ${ }^{(3)}$

2. Tingkat kinerja pada jalan Kinibalu Kota Palangka Raya dapat di lihat dari analisis berikut ini:

a. Hambatan Samping (Side Friction)

1. Hambatan samping (side friction) pada jam puncak terbobot pada pagi hari terjadi pada pukul $06.00-07.00$, dengan nilai terbobot 546,7 termasuk dalam kelas hambatan samping tinggi (high) sedangkan pada siang hari terjadi pada pukul $12.00-13.00$ dengan nilai terbobot 593,5 termasuk dalam kelas hambatan samping tinggi (high) juga.

2. Hambatan samping (side friction) pada jam puncak lalu lintas pada pagi hari terjadi pada pukul 06.15 WIB - 07.15 WIB, dengan nilai terbobot 476,9 termasuk dalam kelas hambatan samping sedang (medium) sedangkan pada siang hari terjadi pada pukul 11.45 WIB 12.45 WIB dengan nilai terbobot 567,3 termasuk dalam kelas hambatan samping tinggi (high).

Dari hasil analisis data hambatan samping (side friction) dapat disimpulkan bahwa hambatan samping yang terjadi pada jalan Kinibalu Palangkaraya termasuk kelas hambatan samping tinggi (high) dengan jenis hambatan samping yang paling dominan yaitu kendaraan parkir atau berhenti dan pada siang hari terdapat PKL (pedagang kaki lima) di sekitar ruas jalan.

b. Kecepatan Arus Bebas (FV):

1. Dari hasil analisis di dapatkan kecepatan arus bebas rata-rata kendaraan campuran, yaitu pada pagi hari sebesar 41,07 $\mathrm{km} / \mathrm{jam}$, dan pada siang hari sebesar $38,50 \mathrm{~km} / \mathrm{jam}$.

2. Dari hasil analisis di dapatkan kecepatan arus bebas kendaraan ringan, yaitu pada pagi hari sebesar $42,85 \mathrm{~km} / \mathrm{jam}$, dan pada siang hari sebesar $40,18 \mathrm{~km} / \mathrm{jam}$.

c. Kapasitas (C), Dari hasil analisis didapatkan kapasitas, yaitu sebesar $2914 \mathrm{smp} / \mathrm{jam}$ terjadi pada pagi hari dan sebesar $2937 \mathrm{smp} / \mathrm{jam}$ pada siang hari untuk total dua arah. d. Derajat Jenuh (DS), Dari hasil analisis di dapatkan derajat jenuh, yaitu pada pagi hari sebesar 0,269, dan pada siang hari sebesar 0,274. Dari hasil analisis menunjukkan bahwa kinerja ruas jalan kinibalu tersebut adalah masih bekerja dengan optimal.

e. Kecepatan Ruang rata-rata $\left(\mathrm{V}_{\mathrm{LV}}\right)$ :

1. Dari hasil analisis di dapatkan kecepatan ruang rata-rata untuk kendaraan campuran, yaitu pada pagi hari sebesar nilai $V_{L V}=38 \mathrm{~km} / \mathrm{jam}$, dan pada siang hari nilai $V_{L V}=36 \mathrm{~km} / \mathrm{jam}$.

2. Dari hasil analisis di dapatkan kecepatan ruang rata-rata untuk kendaraan ringan, yaitu pada pagi hari sebesar nilai $V_{L V}=39$ $\mathrm{km} / \mathrm{jam}$, dan pada siang hari nilai $V_{L y}=$ $37 \mathrm{~km} / \mathrm{jam}$.

Berdasarkan hasil dari analisis terhadap ruas jalan Kinibalu Kota Palangka Raya dengan menggunakan MKJI 1997, dapat disimpulkan bahwa hambatan samping yang terjadi pada jalan Kinibalu Kota Palangka Raya termasuk kelas hambatan samping tinggi (high) dengan jenis hambatan samping yang paling dominan yaitu kendaraan parkir atau berhenti dan pada siang hari terdapat PKL (pedagang kaki lima) di sekitar ruas jalan. Akan tetapi ruas jalan Kinibalu Kota Palangka Raya masih layak berfungsi dan terjadinya kemacetan hanya pada saat jam puncak puncak (peak hour) berlangsung saja. Untuk mengatasi hal tersebut, dapat di berikan tanda rambu dilarang parkir di sekitar jalan, serta pemeliharaan zebra cross yang masih ada.

\section{Saran}

Berdasarkan hasil analisis terhadap hambatan samping jalan kinibalu Palangka Raya dapat diberikan saran yaitu agar dapat di berikan tanda rambu dilarang parkir di sekitar jalan, serta pemeliharaan zebra cross yang masih ada. Diharapkan dengan hasil analisis ini dapat dijadikan sebagai bahan pertimbangan atau masukan untuk penelitian-penelitian selanjutnya yang berhubungan dengan masalah Hambatan Samping seperti meningkatkan kapasitas, mengurangi hambatan samping dan memperkecil kendaraan bergerak lambat. Serta dapat menganalisa kembali menggunakan metode yang berbeda. 
Analisis Hambatan Samping Pada Ruas Jalan Kinibalu ... Ryco $\mathrm{P}^{(1)}$, Nirwana Puspasari( ${ }^{(2)}$, Novrianti ${ }^{(3)}$

\section{DAFTAR PUSTAKA}

Anonim. (1997). Manual Kapasitas Jalan Indonesia. Direktorat Jendral Bina Marga Indonesia. Jakarta

Badan Pusat Statistik. (2015). Statistik Kependudukan Kota Palangka Raya 2015. Badan Pusat Statistik Kota Palangka Raya. Palangka Raya. Diambil dari: https://palangkakota.bps.go.id/index.php/pu blikasi/index?Publikasi\%5BtahunJudnul $\% 5$ $\mathrm{D}=2015 \&$ Publikasi\%5BkataKunci\%5D=ju mlah+penduduk\&yt $0=$ Tampilka (Di Akses 1 April 2017)

Funan, Gideon. Antoni. dkk. (2014). Studi Kinerja Jalan Akibat Hambatan Samping Di Jalan Timor Raya Depan Pasar Oesao Kabupaten Kupang. Jurnal Teknik Sipil Vol. III No 1 April 2014. Fakultas teknik jurusan Teknik Sipil FST Undana-Kupang. Kupang

Morlok, E.K. (1991). Pengantar Teknik dan Perencanaan Transportasi. Erlangga. Jakarta

Rauf, Herman. dkk. (2015). Analisa Kinerja Lalu Lintas Akibat Besarnya Hambatan Samping Terhadap Kecepatan Dengan Menggunakan Regresi Linier Berganda (Studi Kasus Ruas Jalan Dalam Kota Pada Segmen Jalan Lumimuut). Jurnal Sipil Statik Vol.3 No.10 Oktober 2015 (669-684) ISSN: 2337-6732. Fakultas Teknik Universitas Sam Ratulangi Manado. Manado

Sondakh, Gallant. Marunsenge. dkk. (2015). Pengaruh Hambatan Samping Kinerja Pada Ruas Jalan Panjaitan (Kelenteng Ban Hing Kiong) Dengan menggunakan Metode MKJI 1997. Jurnal Sipil Statik. Vol.3 no.8 Agustus 2015 (571-582). ISSN: 23337-6732. Fakultas Teknik Jurusan Sipil Universitas Sam Ratulangi Manado. Manado

Susanto, Edy. Tataming. dkk. (2014). Analisis Besar Kontribusi Hambatan Samping terhadap Kecepatan Dengan Menggunakan Model Regresi Linier Berganda (Studi Kasus: Ruas jalan dalam kota segmen ruas jalan sarapung). Jurnal Sipil Statik. Vol.2 no.1 Januari 2014. (29-36). ISSN: 2337-
6732. Fakultas teknik jurusan sipil universitas sam ratulangi manado. Manado. 